\title{
Lithogenic diet and gallstone formation in mice: integrated response of activities of regulatory enzymes in hepatic cholesterol metabolism
}

\author{
BY EVA REIHNÉR ${ }^{1}$ AND DAGNY STÅHLBERG ${ }^{2}$ \\ Departments of ${ }^{1}$ Surgery and ${ }^{2}$ Medicine, Karolinska Institutet, Huddinge University Hospital, \\ S-14186 Huddinge, Sweden
}

(Received 5 July 1995-Revised 28 March 1996-Accepted 12 April 1996)

\begin{abstract}
Supersaturation of bile with cholesterol is a prerequisite of the development of gallstones. With the intention to study the integrated response of enzymes regulating hepatic cholesterol metabolism during gallstone formation we used an established model for the induction of cholesterol gallstone disease in mice. Ten mice were fed on a lithogenic diet containing $10 \mathrm{~g}$ cholesterol $/ \mathrm{kg}$ and $5 \mathrm{~g}$ cholic acid $/ \mathrm{kg}$ for 8 weeks and were compared with ten mice fed on a standard pellet diet. Cholesterol crystals or gallstones developed in $90 \%$ of gallbladders in treated mice. The lithogenic diet had an inhibitory effect on the ratelimiting enzyme of cholesterol biosynthesis, hepatic 3-hydroxy-3-methylglutaryl-CoA (HMG-CoA) reductase (EC 1.1.1.88) activity, 39.6 (SEM 2.8) v. 171.0 (SEM 47.3) pmol/min per $\mathrm{mg}$ protein. Cholesterol $7 \alpha$-hydroxylase $(E C$ 1.14.13.17) activity, regulating bile acid synthesis, was decreased by $80 \%$, and this was assumed to be due to cholic acid in the diet. The cholesterol-enriched diet also induced a tenfold increase in cholesterol esterification rate in the liver, i.e. acyl-CoA :cholesterol acyl transferase (ACAT; EC 2.3.1.26) activity. The total, as well as esterified, cholesterol contents of liver homogenates were significantly higher in cholesterol- and cholic acid-treated mice and correlated well with the ACAT activity $\left(r_{s} 0.72(P<0.005)\right.$, and $r_{s} 0.68(P<0.01)$ respectively). A significantly higher ACAT activity was obtained in mice given cholesterol and cholic acid even when the enzyme was saturated with exogenous cholesterol, thus indicating an increased amount of the enzyme. The formation of gallstones is dependent on a delicate balance between lithogenic factors (increased absorption of cholesterol and reduced secretion of bile acids) and defence mechanisms (decreased synthesis and increased esterification of cholesterol). In the specific animal model studied here the two defence mechanisms cannot compensate for the increased absorption of cholesterol and the reduced synthesis of bile acids.
\end{abstract}

Lithogenic diet: Hepatic cholesterol metabolism: Gallstones

The formation of gallstones can be thought of in terms of a series of stages: a biochemical abnormality of bile, crystal formation, and stone growth. It is well known that the production of bile supersaturated with cholesterol is the initiating event in the pathogenesis of cholesterol gallstone disease (Admirand \& Small, 1968). Three enzymes regulate hepatic cholesterol metabolism: 3-hydroxy-3-methylglutaryl coenzyme A (HMG-CoA) reductase $(E C 1.1 .1 .88)$ controls the synthesis of cholesterol, cholesterol $7 \alpha$-hydroxylase (EC 1.14.13.17) governs the catabolism of cholesterol to bile acids, and acyl-CoA: cholesterol acyltransferase (ACAT) (EC 2.3.1.26) catalyses the formation of cholesteryl esters, the storage form of cholesterol in the liver (Turley \& Dietschy, 1988).

Humans and baboons are the only species in which gallstones may form spontaneously (Turley \& Dietschy, 1988). Several animal models of cholesterol gallstone formation have been described. By enriching the diet with cholesterol, gallstones can be induced in a number of animal species such as squirrel monkey (Saimiri sciureus), prairie dog (Cynomis spp.) and hamster (Cricetus spp.) (Holzbach, 1984). Previous studies have shown a high 
rate of gallstone formation in mice fed on a diet supplemented with 5-10 g cholesterol $/ \mathrm{kg}$ and $2.5-5.0 \mathrm{~g}$ cholic acid $/ \mathrm{kg}$ (Tepperman et al. 1964; Yamanaka et al. 1986; Rege \& Ostrow, 1995). However, little is known about the regulation of hepatic cholesterol metabolism during gallstone formation in mice. Cholesterol synthesis and the activity of HMG-CoA reductase have not been studied in mice on lithogenic regimens, while cholesterol $7 \alpha$-hydroxylase activity is reported to decrease in mice fed on a cholesterolcholic acid-containing diet (Rege \& Ostrow, 1995). Experiments in rats show that hepatic cholesterol esterification is of regulatory importance for biliary cholesterol secretion (Nervi et al. 1984; Stone et al. 1985). We hypothesized that the formation of lithogenic bile in the mouse model used was the consequence of a disproportionate reduction of cholesterol $7 \alpha-$ hydroxylase activity or a relative inability to increase ACAT activity. We therefore studied the integrated response of the regulatory enzymes of cholesterol metabolism in the liver during gallstone formation.

\section{MATERIALS AND METHODS}

\section{Materials}

$\left[3-{ }^{14} \mathrm{C}\right] \mathrm{HMG}-\mathrm{CoA}$ (specific activity $1924 \mathrm{MBq} / \mathrm{mmol}$ ), and $\left[1-{ }^{14} \mathrm{C}\right] \mathrm{oleoyl} \mathrm{CoA}$ (specific activity $1980 \mathrm{MBq} / \mathrm{mmol}$ ) were obtained from Du Pont Company Biotechnology Systems, Wilmington, DE, USA. Radiolabelled HMG-CoA was diluted to a specific activity of $204 \mathrm{MBq} / \mathrm{mmol}$. DL-[2- $\left.{ }^{3} \mathrm{H}\right]$ mevalonic acid lactone (specific activity $4625 \mathrm{MBq} / \mathrm{mmol}$ ) was obtained from Radiochemical Centre, Amersham, Bucks. and $\left[1,2,6,7-{ }^{3} \mathrm{H}\right]$ cholesteryl oleate (specific activity $3060 \mathrm{MBq} / \mathrm{mmol}$ ) from New England Nuclear Corp., Boston, MA, USA. Unlabelled HMG-CoA, mevalonic acid lactone, cholesteryl oleate, human serum albumin (free of fatty acids), EDTA, NADP, NADPH, glucose-6-phosphate, glucose-6-phosphate dehydrogenase (EC 1.1.1.49), dithiothreitol (DTT), bovine serum albumin and Triton WR-1339 were purchased from Sigma Chemical Co., St Louis, MO, USA. Deuteriumlabelled $7 \alpha$-hydroxycholesterol was synthesized as described previously (Björkhem \& Kallner, 1976). ${ }^{2} \mathrm{H}_{7}$-cholesterol was obtained from Applied Sciences Laboratories Inc., State College, PA, USA.

\section{Experimental procedure}

Male albino NMRI-mice (from Banting \& Kingman (BK), Sollentuna, Sweden) with a mean weight of $28 \mathrm{~g}$ were used in the experiment. Ten control mice were fed on a standard pellet diet containing $165 \mathrm{~g}$ protein, $40 \mathrm{~g}$ fat and $580 \mathrm{~g}$ carbohydrates $/ \mathrm{kg}$ (EWOS AB, Södertälje, Sweden). Another ten mice were fed on a lithogenic diet, normal pellets supplemented with $10 \mathrm{~g}$ cholesterol $/ \mathrm{kg}$ and $5 \mathrm{~g}$ cholic acid $/ \mathrm{kg}$. All mice had free access to water and chow. After 2 months of dietary treatment all mice in both groups were killed by cervical dislocation at 08.00 hours. Anaesthetic agents were not used in order to avoid any interference with the hepatic enzyme activities. Via a thoracotomy, blood was obtained from the opened heart. The gallbladder was then removed and the liver was excised and weighed. The liver was divided into two pieces that were put into cold buffer solutions and immediately analysed. The study was approved by the Ethical Committee for animal experiments at Lantbruksstyrelsen, Jönköping, Sweden.

\section{Preparation of liver microsomes}

One aliquot of the liver biopsy was weighed and placed into nine volumes $(\mathrm{v} / \mathrm{w})$ of ice-cold $50 \mathrm{~mm}$-Tris-HCl buffer, $\mathrm{pH} 7 \cdot 4$, containing $0.3 \mathrm{M}$-sucrose, $10 \mathrm{mM}$-EDTA, $10 \mathrm{~mm}$-DTT and $50 \mathrm{mM}-\mathrm{NaCl}$. The remaining piece of the liver, used for the ACAT assay, was placed in the same buffer to which $1 \mathrm{mM}$-EDTA was added and DTT was excluded. The liver specimens were minced and homogenized with a loose-fitting Teflon pestle and the microsomal 
fraction was prepared by ultracentrifugation as described previously (Angelin et al. 1984). The microsomal content of protein was determined by the method of Lowry et al. (1951).

\section{Assay of microsomal hydroxymethylglutaryl-CoA reductase activity}

A portion of the microsomal fraction, $40 \mu \mathrm{l}$, was preincubated for $15 \mathrm{~min}$ at $37^{\circ}$, and the HMG-CoA reductase assay was then initiated by the addition of $90 \mathrm{nmol}\left[3-{ }^{14} \mathrm{C}\right] \mathrm{HMG}-$ CoA, $0.0185 \mathrm{MBq}$. The incubation was run for $15 \mathrm{~min}$ and was stopped by the addition of $6 \mathrm{M}-\mathrm{HCl}$. Tritium-labelled mevalonic acid, $0.37 \mathrm{KBq}$, was added as internal standard together with $3 \mathrm{mg}$ unlabelled mevalonic acid lactone. After lactonization the mevalonic acid lactone formed was isolated by TLC and counted in a liquid-scintillation spectrometer. Correction for losses was made by the internal standard. Further details about the method are given by Angelin et al. (1984).

\section{Assay of microsomal cholesterol $7 \alpha$-hydroxylase activity}

The activity of cholesterol $7 \alpha$-hydroxylase was assayed as described by Einarsson $e t$ al. (1986). The standard assay system consisted of $0.5 \mathrm{ml}$ of the microsomal fraction and $0.5 \mathrm{ml}$ 0.1 M-phosphate buffer, $\mathrm{pH} 7 \cdot 4$, containing $1 \mathrm{~mm}$-EDTA, and $1 \mathrm{mM}-\mathrm{NADPH}$. After $15 \mathrm{~min}$ incubation at $37^{\circ}$ the reaction was stopped and deuterium-labelled $7 \alpha$-hydroxycholesterol was added as internal standard. The amount of $7 \alpha$-hydroxycholesterol formed was determined by combined GLC-mass spectrometry and was expressed as pmol/min per $\mathrm{mg}$ protein.

\section{Assay of acyl CoA:cholesterol acyltransferase}

ACAT activity was assayed in both the absence and presence of exogenous cholesterol as described previously (Einarsson et al. 1989). The assay system contained $0.1 \mathrm{ml}$ of the microsomal preparation, $0 \cdot 1 \mathrm{M}$-phosphate buffer ( $\mathrm{pH} 7 \cdot 4), 1 \mathrm{~mm}$-EDTA, and $1 \mathrm{mg}$ fattyacid-free bovine serum albumin in a total volume of $1.0 \mathrm{ml}$. The mixture was preincubated for $5 \mathrm{~min}$ at $37^{\circ}$, or for $30 \mathrm{~min}$ at $37^{\circ}$ after the addition of $50 \mathrm{nmol}$ exogenous cholesterol (dissolved in $0.6 \mathrm{mg}$ Triton). The reaction was started by the addition of $25 \mathrm{nmol}$ $(0.054 \mathrm{MBq})$ of $\left[{ }^{14} \mathrm{C}\right]$ oleoyl $\mathrm{CoA}$. The assay was stopped after $4 \mathrm{~min}$, and tritium-labelled cholesteryl oleate $(0.37 \mathrm{kBq})$ was added as internal standard. The cholesteryl oleate formed was isolated by TLC and the radioactivity counted in a liquid-scintillation spectrometer.

\section{Analysis of serum lipids and hepatic cholesterol}

Plasma cholesterol was measured by an enzymic method (cholesterol esterase-cholesterol oxidase-peroxidase; Boehringer Mannheim) and triacylglycerols were assayed by an enzymic method without correction for free glycerol (lipase-glycerol kinase-glycerol phosphate oxidase-peroxidase; Boehringer Mannheim). The concentrations of total and free cholesterol in liver homogenates and microsomal fractions were determined by isotope dilution-mass spectrometry after the addition of deuterium-labelled cholesterol as an internal standard, as described previously (Schaffer et al. 1982). Free cholesterol was determined by the same method except that saponification with alcoholic $\mathrm{KOH}$ was omitted. The concentration of esterified cholesterol was calculated as the difference between total and free cholesterol in the same sample.

\section{Statistical analysis}

Data are expressed as means with their standard errors. The statistical significance of differences was evaluated with the Mann-Whitney test and Wilcoxon signed rank test. Correlations were tested by calculating Spearman's rank order correlation coefficient, $r_{s}$. 
Table 1. Body weight, liver weight and serum lipids in mice fed on a normal chow diet or a lithogenic diet $\dagger$

(Mean values with their standard errors)

\begin{tabular}{lcccccc}
\hline & \multicolumn{2}{c}{ Controls $(n$ 10) } & & \multicolumn{2}{c}{ Lithogenic diet $(n$ 10) } \\
\cline { 2 - 3 } \cline { 5 - 6 } & & Mean & SEM & & Mean & SEM \\
\hline Body wt $(\mathrm{g})$ & $32 \cdot 9$ & $0 \cdot 6$ & & $33 \cdot 9$ & $0 \cdot 7$ \\
Liver wt $(\mathrm{g})$ & $1 \cdot 5$ & $0 \cdot 1$ & & $2 \cdot 3^{* * *}$ & $0 \cdot 1$ \\
Serum total cholesterol $(\mathrm{mmol} / \mathrm{l})$ & $2 \cdot 4$ & $0 \cdot 1$ & & $2 \cdot 9^{*}$ & $0 \cdot 2$ \\
Serum total triacylglycerols $(\mathrm{mmol} / \mathrm{l})$ & $1 \cdot 4$ & $0 \cdot 2$ & & $1 \cdot 0$ & $0 \cdot 1$ \\
\hline \hline
\end{tabular}

Mean values were significantly different from those for controls: $* P<0 \cdot 02$, *** $P<0.001$.

$\dagger$ For details of diets and procedures, see pp. 766-767.

\section{RESULTS}

The cholesterol-enriched lithogenic diet was well accepted by the mice. The mean gain of body weight was $6 \mathrm{~g}$ after 2 months and was not significantly different from that of the control group (Table 1). The livers were enlarged by feeding cholesterol. Morphologically very mild to moderate fatty changes were seen as assessed by the number of fat vacuoles in the hepatocytes and their distribution in the liver lobuli in haematoxylin-eosin-stained preparations.

Gallbladder contents were examined for rhomboid monohydrate cholesterol crystals by polarizing light microscopy. Cholesterol crystals were present in the gallbladder bile in all but one of the cholesterol-treated mice but were not present in gallbladder bile from any mouse fed on normal chow. Gallstones visible to the naked eye were observed in all but three of the gallbladders after 2 months on the lithogenic diet, and not in any gallbladder from the control animals. The gallstones measured between 0.5 and $1 \mathrm{~mm}$ in size and were found in a number of one to seven per gallbladder. Although the gallbladders in the diet group as a rule were distended to a size of between $1 \times 3.5 \mathrm{~mm}$ to $6 \times 3.5 \mathrm{~mm}$, the amount of gallbladder bile was too small for analysis since some of the gallbladders were filled with stones. Moreover many bile samples were noticeably viscous.

Cholesterol levels in serum were significantly higher in mice fed on the supplemented diet than in the controls $(2.9$ (SEM 0.2) v. 2.4 (SEM 0.1$) \mathrm{mmol} / 1 ; P<0.05)$ while serum triacylglycerol levels were not different.

The effects of the lithogenic diet on the rate-limiting enzymes of hepatic cholesterol metabolism are shown in Table 2. HMG-CoA reductase activity was about $75 \%$ lower in mice fed on the lithogenic diet compared with the controls. Cholesterol $7 \alpha$-hydroxylase activity was $80 \%$ lower in mice fed on the diet supplemented with cholesterol and cholic acid. ACAT activity was ten times higher in mice fed on the lithogenic diet. Addition of cholesterol as substrate to the assay system resulted in a significant increase of the enzyme activity in the controls $(P<0 \cdot 01)$ as well as in the mice fed on the lithogenic $\operatorname{diet}(P<0.05)$. The ACAT activity, when saturated with cholesterol, was nearly eightfold higher in the cholesterol-fed mice. The increased ACAT activity gave rise to a doubling of the percentage of esterified cholesterol $(61 \%$ v. $26 \%$ ) in whole liver homogenates (Table 3). Positive correlations between hepatic cholesterol content and ACAT activity were also seen as follows: homogenate total cholesterol $r_{s} 0.72, P<0.005$; homogenate esterified cholesterol $r_{s} 0.68, P<0.01$; microsomal total cholesterol $r_{s} 0.53, P<0.05$ and microsomal esterified cholesterol $r_{s} 0.68, P<0.01$. 
Table 2. Hepatic microsomal enzyme activities ( $\mathrm{pmol} / \mathrm{min}$ per $\mathrm{mg}$ protein) in mice fed on a normal chow diet or a lithogenic diet $\ddagger$

(Mean values with their standard errors)

\begin{tabular}{|c|c|c|c|c|}
\hline \multirow[b]{2}{*}{ Enzyme } & \multicolumn{2}{|c|}{ Controls $(n 9)$} & \multicolumn{2}{|c|}{ Lithogenic diet $(n 9)$} \\
\hline & Mean & SEM & Mean & SEM \\
\hline HMG-CoA reductase $(E C 1,1.1 .88)$ & $171 \cdot 0$ & $47 \cdot 3$ & $39 \cdot 6^{*}$ & $2 \cdot 8$ \\
\hline Cholesterol $7 \alpha$-hydroxylase ( $E C 1,14,13.17)$ & $36 \cdot 1$ & 3.6 & $6 \cdot 7^{* * *}$ & $2 \cdot 0$ \\
\hline $\operatorname{ACAT}(E C 2.3 .1 .26)$ & 330 & 38 & $3330 * * *$ & 306 \\
\hline ACAT + exogenous cholesterol\$ & $858+\dagger$ & 50 & $6080^{* * *+}$ & 442 \\
\hline
\end{tabular}

HMG-CoA reductase, hydroxymethylglutaryl-CoA reductase; ACAT, acyl-CoA: cholesterol acyltransferase. Mean values were significantly different from those for controls: $* P<0 \cdot 05, * * * P<0.001$.

Mean values were significantly different from those for ACAT without cholesterol: $\uparrow P<0.05, \uparrow+P<0.01$.

For details of diets and procedures, see pp. 766-767.

$\S$ ACAT activity was assayed in the absence and presence of cholesterol, see p. 767.

Table 3. Cholesterol content of homogenates and microsomal fractions of livers from mice fed on a normal chow diet or a lithogenic diet $\dagger$

(Mean values with their standard errors)

\begin{tabular}{|c|c|c|c|c|}
\hline & \multicolumn{2}{|c|}{ Controls ( $n$ 9) } & \multicolumn{2}{|c|}{ Lithogenic diet ( $n$ 9) } \\
\hline & Mean & SEM & Mean & SEM \\
\hline \multicolumn{5}{|c|}{ Homogenates (nmol/mg protein) } \\
\hline Total cholesterol & $30 \cdot 3$ & $2 \cdot 0$ & $99 \cdot 2 * * *$ & $14 \cdot 1$ \\
\hline Free cholesterol & 22.5 & $1 \cdot 2$ & $38 \cdot 3^{* * *}$ & $3 \cdot 2$ \\
\hline Esterified cholesterol & 7.8 & $1 \cdot 1$ & $61 \cdot 0^{* * *}$ & $11 \cdot 9$ \\
\hline \multicolumn{5}{|c|}{ Microsomes (nmol/mg protein) } \\
\hline Total cholesterol & $50 \cdot 0$ & $5 \cdot 3$ & $87 \cdot 7 * *$ & 8.6 \\
\hline Free cholesterol & $44 \cdot 4$ & $4 \cdot 2$ & $76 \cdot 0^{* *}$ & $8 \cdot 1$ \\
\hline Esterified cholesterol & $5 \cdot 6$ & $2 \cdot 0$ & $11 \cdot 7 * *$ & 1.9 \\
\hline
\end{tabular}

Mean values were significantly different from those for controls: ${ }^{* *} P<0.01,{ }^{* * *} P<0.001$

$\dagger$ For details of diets and procedures, see pp. 766-767.

\section{DISCUSSION}

The liver accounts for up to half of whole-body cholesterol synthesis in species such as the rat and squirrel monkey (Turley \& Dietschy, 1988). The other major source of cholesterol is dietary cholesterol absorbed via the intestine. Larger animals and humans generally synthesize and absorb much less cholesterol per unit body weight than do small experimental animals. This high capacity for cholesterol absorption from the diet in such animals as hamster, prairie dog and mouse has been used in various animal models to induce cholesterol gallstone formation. In the present study mice were fed on a diet containing both cholesterol $(10 \mathrm{~g} / \mathrm{kg})$ and cholic acid $(5 \mathrm{~g} / \mathrm{kg})$ since cholic acid has to be added to the cholesterol-supplemented diet for gallstones to be formed in mice, according to the findings of Tepperman et al. (1964). After 2 months on the lithogenic diet, cholesterol crystals or gallstones occurred in all but one of the mice, which is in accordance with previous reports (Tepperman et al. 1964; Caldwell et al. 1965; Yellin et al. 1973; Yamanaka et al. 1986). Bile lipid concentrations were not measured in the present study but have been investigated by others in gallbladder bile pooled from several mice. From these reports it can 
be postulated that in mice fed on a cholesterol-cholic acid-containing diet the cholesterol concentration of gallbladder bile increases considerably (Tepperman et al. 1964; Caldwell et al. 1965; Yellin et al. 1973; Whiting \& Watts, 1987). The specific role of cholic acid in the lithogenic diet in mice has also been investigated. One important mechanism of action of cholic acid is to promote cholesterol absorption in the intestine while other supplementary bile acids such as chenodeoxycholic acid and ursodeoxycholic acid inhibit cholesterol absorption (Reynier et al. 1981; Whiting \& Watts, 1987; Uchida et al. 1991). In a recent report, however, two strains of mice did not increase their cholesterol absorption when fed on a cholesterol-rich diet containing taurocholate (Dueland et al. 1993).

In the present study the lithogenic diet caused a pronounced inhibition of hepatic cholesterol synthesis in mice, seen as a $75 \%$ reduction in $\mathrm{HMG}-\mathrm{CoA}$ reductase activity. The role of bile acids in down-regulating HMG-CoA reductase has been studied in rats (Heuman et al. 1988; Spady \& Cuthbert, 1992). Cholesterol synthesis in this species was suppressed by more than $95 \%$ with dietary cholesterol while the hydrophobic bile acids cholic acid and chenodeoxycholic acid suppressed cholesterol synthesis to a lesser extent. The hydrophilic bile acid ursodeoxycholic acid had no effect. HMG-CoA reductase mRNA levels have been determined in livers from mice (Rudling, 1992) and rats (Spady \& Cuthbert, 1992) fed on diets supplemented with cholic acid or cholesterol. In comparison with the HMG-CoA reductase activity, a less pronounced (40\%) suppression of HMGCoA reductase mRNA levels was seen with both diets. It was therefore suggested that cholesterol synthesis is predominantly controlled by post-transcriptional regulation of HMG-CoA reductase activity (Spady \& Cuthbert, 1992).

In our present study the cholesterol-cholic acid-containing diet reduced cholesterol $7 \alpha-$ hydroxylase activity by about $80 \%$. Nakamura-Yamanaka et al. (1987) showed a similar effect on cholesterol $7 \alpha$-hydroxylase activity in mice fed on a lithogenic diet containing $5 \mathrm{~g}$ cholesterol $/ \mathrm{kg}$ and $2 \cdot 5 \mathrm{~g}$ sodium cholate $/ \mathrm{kg}$. Since it has been reported that feeding with cholic acid may suppress bile acid synthesis in the rat (Shefer et al. 1973; Heuman et al. 1988), the present inhibition on bile acid synthesis is most probably due to cholic acid in the diet. Rudling (1992) reported a suppression of $7 \alpha$-hydroxylase mRNA in mice when cholic acid was present in the diet and increased mRNA on feeding pure cholesterol only. This latter effect was seen when the diet contained $17 \mathrm{~g}$ cholesterol $/ \mathrm{kg}$ or more. Similar results were obtained by Spady \& Cuthbert (1992) in rats. Thus the addition of cholic acid to the diet is likely to reduce cholesterol breakdown to bile acids, and consequently increase biliary cholesterol secretion.

In accordance with results of other studies we found a significant increase in liver size when cholesterol was added to the diet (Bergman et al. 1970; Whiting \& Watts, 1987; Spady \& Cuthbert, 1992). This was associated with a threefold higher amount of total cholesterol and an eightfold higher concentration of esterified hepatic cholesterol. We also found a tenfold higher ACAT activity in mice fed on the lithogenic diet. ACAT activity showed a positive correlation with changes in both microsomal and whole-liver total and esterified cholesterol contents. However, the elevated ACAT activity may still be insufficient to prevent hypersecretion of cholesterol into bile and gallstone formation. In rats, on the other hand, the hepatic ACAT activity seems to be correlated in a reciprocal manner to the biliary cholesterol output (Nervi et al. 1984).

It has been suggested previously that ACAT is not a true rate-limiting enzyme, only reflecting the availability of free cholesterol in the vicinity of the enzyme (Suckling \& Stange, 1985). We found that addition of exogenous cholesterol to the microsomal preparation increased the ACAT activity in both controls and cholesterol-fed mice, but the ACAT activity was still nearly eightfold higher in the cholesterol-fed mice. Similar results were obtained recently in cholesterol-fed rabbits by Pape et al. (1995). They also 
demonstrated an increase in hepatic ACAT mRNA levels. These observations suggest that the supply of free cholesterol is an important regulatory factor of ACAT activity.

It is evident that the formation of gallstones is dependent on a delicate balance between lithogenic factors (increased absorption of cholesterol and reduced secretion of bile acids) and defence mechanisms (decreased synthesis and increased esterification of cholesterol). To our knowledge the three key enzymes in cholesterol homeostasis have not previously been assayed simultaneously during gallstone formation in experimental animals. In the specific model used here the two very active defence mechanisms could not compensate for the increased absorption of cholesterol and reduced synthesis of bile acids. The relative importance of the lithogenic factors and defence mechanisms may, however, vary from species to species. The role of intestinal absorption of dietary cholesterol seems to require further research.

The authors thank Ms Gunvor Alvelius, Ms Lisbet Benthin, Ms Ingela Arvidsson for skilful technical assistance and Ms Hélène Jansson for editorial assistance. This study was supported by the Swedish Medical Research Council (projects 03X-04793, 03X-3141) and the Karolinska Institute.

\section{REFERENCES}

Admirand, W. H. \& Small, D. M. (1968). The physicochemical basis of cholesterol gallstone formation in man. Journal of Clinical Investigation 47, 1043-1052.

Angelin, B., Einarsson, K., Liljeqvist, L., Nilsell, K. \& Heller, R. A. (1984). 3-Hydroxy-3-methylglutaryl coenzyme A reductase in human liver microsomes: active and inactive forms and cross-reactivity with antibody against rat liver enzyme. Journal of Lipid Research 25, 1159-1166.

Bergman, F., Juul, A. H. \& van der Linden, W. (1970). Development and regression of morphological and biochemical changes in hamsters and mice fed a cholesterol cholic acid containing diet. Acta Pathologica et Microbiologica Scandinavica 78, 179-191.

Björkhem, I. \& Kallner, A. (1976). Hepatic $7 \alpha$-hydroxylation of cholesterol in ascorbate deficient and ascorbatesupplemented guinea pigs. Journal of Lipid Research 17, 360-365.

Caldwell, F. T., Levitsky, K. \& Rosenberg, B. (1965). Dietary production and dissolution of cholesterol gallstones in the mouse. American Journal of Physiology 209, 473-478.

Dueland, S., Drisko, J., Graf, L., Machleder, D., Lusis, A. J. \& Davis, R. A. (1993). Effect of dietary cholesterol and taurocholate on cholesterol $7 \alpha$-hydroxylase and hepatic LDL receptors in inbred mice. Journal of Lipid Research 34, 923-931.

Einarsson, K., Angelin, B., Ewerth, S., Nilsell, K. \& Björkhem, I. (1986). Bile acid synthesis in man: assay of hepatic microsomal cholesterol $7 \alpha$-hydroxylase activity by isotope dilution-mass spectrometry. Journal of Lipid Research 27, 82-88.

Einarsson, K., Benthin, L., Ewerth, S., Hellers, G., Ståhlberg, D. \& Angelin, B. (1989). Studies on acyl-coenzyme A:cholesterol acyltransferase activity in human liver microsomes. Journal of Lipid Research 30, 739-746.

Heuman, D. M., Vlahcevic, Z. R., Bailey, M. L. \& Hylemon, P. B. (1988). Regulation of bile acid synthesis. II. Effect of bile acid feeding on enzymes regulating hepatic cholesterol and bile acid synthesis in the rat. Hepatology 8, 892-897.

Holzbach, R. T. (1984). Animal models of cholesterol gallstone disease. Hepatology 4, 191S-198S.

Lowry, O. H., Rosebrough, N. J., Farr, A. L. \& Randall, R. J. (1951). Protein measurement with the Folin phenol reagent. Journal of Biological Chemistry 193, 265-275.

Nakamura-Yamanaka, Y., Tsuji, K. \& Ichikawa, T. (1987). Effect of dietary taurine on cholesterol $7 \alpha-$ hydroxylase activity in the liver of mice fed a lithogenic diet. Journal of Nutritional Science and Vitaminology 33, 239-243.

Nervi, F., Bronfman, M., Allalo'n, W., Depiereux, E. \& Del Pozo, R. (1984). Regulation of biliary cholesterol secretion in the rat. Role of hepatic cholesterol esterification. Journal of Clinical Investigation 74, 2226-2237.

Pape, M. E., Schultz, P. A., Rea, T. J., De Mattos, R. B., Kieft, K., Bisgaier, C. L., Newton, R. S. \& Krause, B. R. (1995). Tissue specific changes in acyl-CoA:cholesterol acyltransferase (ACAT) mRNA levels in rabbits. Journal of Lipid Research 36, 823-838.

Rege, R. V. \& Ostrow, J. D. (1995). Animal models of pigment and cholesterol gallstone disease. In Methods in Biliary Research, pp 203-243 [M. Muraca, editor]. Boca Raton, FL: CRC Press.

Reynier, M. O., Montet, J. C., Gerolami, A., Marteau, C., Crotte, C., Montet, A. M. \& Mathieu, S. (1981). Comparative effects of cholic, chenodeoxycholic, and ursodeoxycholic acids on micellar solubilization and intestinal absorption of cholesterol. Journal of Lipid Research 22, 467-473. 
Rudling, M. (1992). Hepatic mRNA levels of the LDL receptor and HMG-CoA reductase show coordinate regulation in vivo. Journal of Lipid Research 33, 493-501.

Schaffer, R., Sniegoski, L. T., Welch, M. J., White, V. A., Cohen, H. S., Hertz, J., Mandel, R. C., Paule, L., Svensson, L., Björkhem, I. \& Blomstrand, R. (1982). Comparison of two isotope dilution mass spectrometric methods for determination of total serum cholesterol. Clinical Chemistry 28, 5-8.

Shefer, S., Hauser, S., Lapar, V. \& Mosbach, E. H. (1973). Regulatory effects of sterols and bile acids on hepatic 3-hydroxy-3-methylglutaryl CoA reductase and cholesterol $7 \alpha$-hydroxylase in the rat. Journal of Lipid Research 14, 573-580.

Spady, D. K. \& Cuthbert, A. (1992). Regulation of hepatic sterol metabolism in the rat. Parallel regulation of activity and mRNA for 7 -hydroxylase but not 3-hydroxy-3-methylglutaryl coenzyme A reductase or low density lipoprotein receptor. Journal of Biological Chemistry 267, 5584-5591.

Stone, B. G., Erickson, S. K., Craig, W. Y. \& Cooper, A. D. (1985). Regulation of rat biliary cholesterol secretion by agents that alter intrahepatic cholesterol metabolism. Evidence for a distinct biliary precursor pool. Journal of Clinical Investigation 76, 1773-1781.

Suckling, K. E. \& Stange, E. F. (1985). Role of acyl-CoA:cholesterol acyltransferase in cellular cholesterol metabolism. Journal of Lipid Research 26, 647-671.

Tepperman, J., Caldwell, F. T. \& Tepperman, H. M. (1964). Induction of gallstones in mice by feeding a cholesterol-cholic acid containing diet. American Journal of Physiology 206, 628-640.

Turley, S. D. \& Dietschy, J. M. (1988). The metabolism and excretion of cholesterol by the liver. In The Liver: Biology and Pathobiology 2nd ed., pp, 617-641 [I. M. Arias, W. B. Jakoby, H. Popper, D. Schachter and D. A. Shafritz, editors]. New York: Raven Press.

Uchida, K., Akiyoshi, T., Igimi, H., Takase, H., Nomura, Y. \& Ishihara, S. (1991). Differential effects of ursodeoxycholic acid and ursocholic acid on the formation of biliary cholesterol crystals in mice. Lipids 26, 526-530.

Whiting, M. J. \& Watts, J. McK. (1987). Role of cholic acid in the dietary induction of cholesterol gall-bladder stones in mice. Journal of Gastroenterology and Hepatology 2, 547-555.

Yamanaka, Y., Tsuji, K. \& Ichikawa, T. (1986). Simulation of chenodeoxycholic acid excretion in hypercholesterolemic mice by dietary taurine. Journal of Nutritional Science and Vitaminology 32, $287-296$.

Yellin, T. O., Klaiber, M. S. \& Webb, E. (1973). Lithogenic effects of cholic acid and chenodeoxycholic acid in the cholesterol fed mouse. Biochimica et Biophysica Acta 320, 478-485. 